Brit. J. industr. Med., 1952, 9, 32.

\title{
THE DETERMINATION OF SMALL AMOUNTS OF TETRANITROMETHANE IN AIR
}

\author{
BY \\ V. B. VOUK and O. A. WEBER \\ From the Institute of Industrial Hygiene, Zagreb, Yugoslavia
}

(RECEIVED FOR PUBLICATION OCTOBER 17, 1951)

Tetranitromethane (T.N.M.) occurs in the production of T.N.T. as a byproduct of toluene nitration. It is a highly toxic substance, and its toxic properties have been recently investigated by Sievers, Rushing, Gay, and Monaco (1947). According to them, the maximum allowable concentration of T.N.M. is less than 5 p.p.m. Elkins (1950) recommends 0.5 p.p.m. or $4 \mathrm{mg} . / \mathrm{m}^{3}$ of air as the safe maximum allowable concentration. Unless we are prepared to take very large air samples, the analytical method for determining T.N.M. should enable us to determine with precision as little as $20 \mu \mathrm{g}$., that is, the amount of T.N.M. in a 5 litre air sample, if the concentration of the contaminant equals the maximum allowable concentration. As the volume of absorption liquid usually does not exceed $10 \mathrm{ml}$., a reliable analytical method should register with sufficient precision a concentration of $2 \mu \mathrm{g}$. of T.N.M. per millilitre of the solution.

Baillie, Macbeth, and Maxwell (1920) describe a method for determining T.N.M. based on the reduction of T.N.M. by hydrazine. The nitrogen evolved during the reduction is determined volumetrically. However, this method does not seem sensitive enough for industrial practice, since only $0.2 \mathrm{ml}$. of nitrogen is produced per $35 \mathrm{mg}$. of T.N.M. A colour reaction between dioxane and T.N.M. is described by Reid and Hoffmann (1929). This reaction is used to indicate the presence of dioxane, and we tried to invert and adapt it for the determination of T.N.M., but without success, its sensitivity being insufficient. The method of Kranz and Stepanek (1937), based on the fact that iodine is liberated when potassium iodide is added to a solution of T.N.M., can be used only for determining larger quantities of T.N.M. (0.05-0.12\%). Ehrenberg, Fisher, and Löfgren (1945) determined small quantities of T.N.M. by means of the GriessIlosvay reaction, which, however, is not specific for T.N.M., and other contaminants such as nitrous gases would interfere if present. The polarographic method of Cruse and Haul (1949) would be satisfactory with regard to sensitivity $(9.8$ to $98 \mu \mathrm{g} . / \mathrm{ml}$.), but if $\mathrm{m}$-dinitrobenzene or $\mathrm{s}$-trinitrobenzene are present, a preliminary separation of T.N.M. by vacuum distillation becomes necessary. Thus only the method of Sievers and others seemed to satisfy the requirements both with regard to sensitivity and simplicity. However, there remained several points to be cleared up before the method of Sievers and his colleagues could be accepted with complete confidence. The method is based on a colour reaction between T.N.M. and benzidine in ethanol. One of the problems studied in this paper is the stability of the colour produced by mixing alcoholic solutions of T.N.M. and benzidine. Sievers states that " the colour is sufficiently stable, but not stable enough to permit the use of the same set of standards for comparison with samples made up at other times ". When preparing the calibration curve according to the procedure of Sievers and others we noticed that the optical density of a sample made twice in the same way could not be reproduced. This induced us to study in the first place the influence of light on the intensity of the colour reaction. Other problems we studied were the optimum amount of benzidine, the influence of the design of the apparatus for measuring the optical density, the influence of ageing of the T.N.M. solution on the intensity of the colour reaction, the influence of various other contaminants such as nitrobenzene, $\mathrm{HNO}_{3}$, and finally the efficiency of the sampling procedure.

\section{Experimental}

Chemicals. - The following were used :-

Tetranitromethane synthetized according to Poe Liang (1941) $\mathrm{n}_{\mathrm{D}}^{16 \cdot 4}=1 \cdot 44145$.

Ethanol, commercial, 96\%, redistilled. 
Pyridine, pure (Schering-Kahlbaum, Berlin).

Benzidine, purest (Schering-Kahlbaum, Berlin).

Density Measurements.-Density* measurements were performed with a Beckman spectrophotometer, model DU, a Fisher electrophotometer, A.C. model, and a Pulfrich photometer (C. Zeiss, Jena). All measurements with the Beckman spectrophotometer were carried out at $\lambda=400 \mathrm{~m} \mu$ with a slit of $0.06 \mathrm{~mm}$. Light filters B with maximum transmission at $425 \mathrm{~m} \mu$ and $\mathrm{K}-8 \mathrm{a}-\mathrm{VI}$ (blue) were used with the Fisher and Pulfrich photometers respectively. The optical path length was 1.002 for the Beckman and 0.999 for the Pulfrich photometer. Cylindrical cells, of $1.2 \mathrm{~cm}$. diameter, were used in the Fisher electrophotometer.

Mixtures of T.N.M. and air of known concentration were prepared with an apparatus similar to that described by Scott (1943). The colour reaction was performed by adding a measured amount of benzidine solution in ethanol (1.00 g./litre) to the T.N.M. solution in ethanol, the $p \mathrm{H}$ of which was brought to 6 by means of pyridine.

Influence of Light on Intensity of Colour Reaction

The influence of light on the intensity of colour reaction is shown in the Fig. 1.

The reaction was carried out in daylight. The

$* d=\log \frac{I_{0}}{I} ; I_{o}=$ intensity of light transmitted through benzidine solution, $\mathbf{I}=$ intensity of light transmitted through reaction mixture. absorption cell was filled with the reaction mixture and put immediately into the compartment of the Beckman spectrophotometer. A combination of the ordinary cell compartment and the fluorescence accessory set enabled us to illuminate the reaction mixture and to measure the density at the same time. When the cell was not illuminated, the optical density of the reaction mixture increased first very rapidly, then more slowly, reaching finally a maximum value. As soon as the light was put on, the optical density fell. After 15 to 20 minutes the density stabilized itself again at a value $25 \%$ lower than the maximum density. When the light is put off again, the density increases but not so rapidly as the first time. After the light was switched off the density fell for a short time below the stable minimum value before starting to increase. This phenomenon could easily be reproduced, but it was difficult to explain it. It may be due to the imperfection of the measuring apparatus in which there was a considerable distance between the slit and the photocell caused by the combination of the ordinary cell compartment and the fluorescence accessory set. This defect has also been described by, for example, Gibson and Balcom (1947). Therefore, if we want to perform the colour reaction under the conditions of maximum sensitivity, the

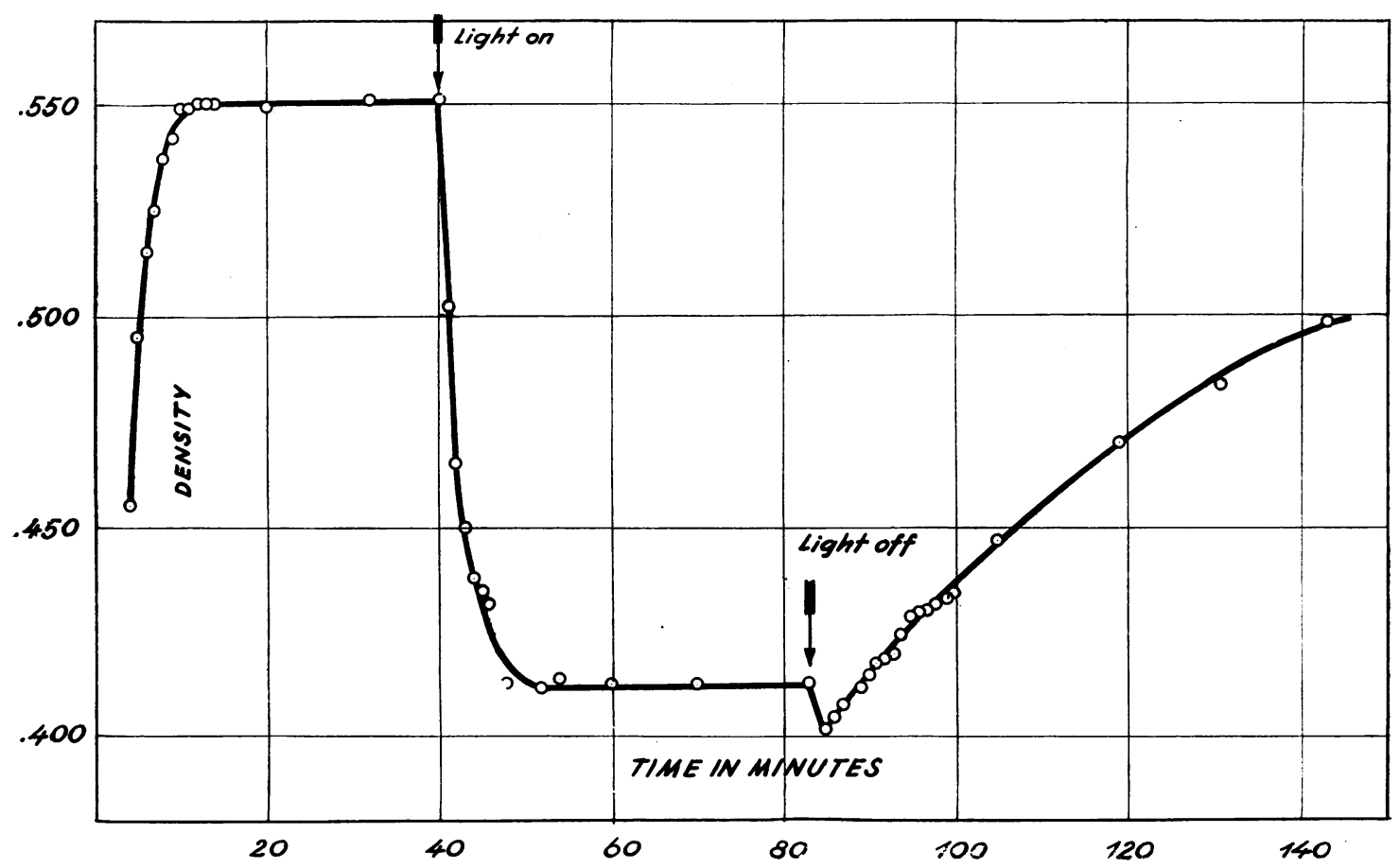

Fig. 1.-Graph showing the influence of light on the intensity of colour reaction : benzidine-tetranitromethane. Reaction mixture : 6.9 $\mu \mathrm{g} . / \mathrm{ml}$. T.N.M. + benzidine $0.04 \mathrm{mg} . / \mathrm{ml}$. Adapted Beckman spectrophotometer with $\lambda=400 \mathrm{m \mu}$; slit $0.06 \mathrm{~mm}$. 
light should be excluded. The measurement of density should not be performed earlier than 15 to 20 minutes after the reaction components are brought together.

\section{Influence of Benzidine Concentration}

If the concentration of benzidine is increased, the density of the reaction mixture also increases until an optimum concentration of benzidine is reached. A further increase in the benzidine concentration has a much smaller effect on density. This course is shown on Fig. 2 for two different T.N.M. concentrations. The optimum concentration of T.N.M. varies a little with the concentration of benzidine, but for the range of T.N.M. concentrations investigated $(0-15 \mu \mathrm{g} . / \mathrm{ml}$.), the optimum concentration of benzidine can be assumed to be $0.2 \mathrm{~g}$./litre. The greater the concentration of benzidine, the shorter is the time interval necessary for density to reach its constant value.

\section{Calibration Curves}

Fig. 3 shows the calibration curves for three different photometers. The calibration curves are straight lines as required by Lambert-Beer's law. The Beckman spectrophotometer gives the highest rate of increase of density with concentration of

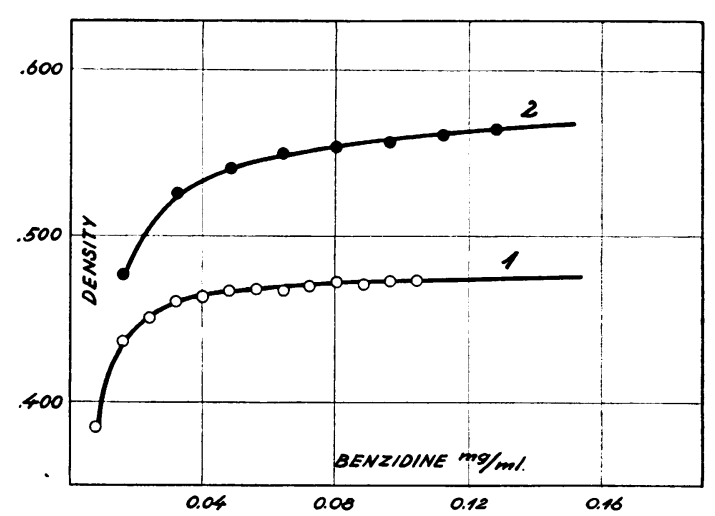

FIG. 2.-Graph showing the influence of benzidine concentration. Curve 1 relates to T.N.M. concentration of $6.0 \mathrm{~kg} . / \mathrm{ml}$. Curve 2 relates to T.N.M. concentration of $10.0 \mu \mathrm{g} . / \mathrm{ml}$. Plotting increment for the abscissae of curve 2 is $-0 \cdot 200$. Beckman spectrophotometer with $\lambda=400 \mathrm{~m} \mu$; slit $0.06 \mathrm{~mm}$.

T.N.M. (straight line No. 1). The linear relation between density and concentration can be described by the equation

$$
\mathrm{d}=\mathbf{0 . 0 8 0 8 \mathrm { c }}
$$

where $d=\log I_{0} / I=$ density and $c=$ concentration of T.N.M. in mg./litre.

The light transmission of the coloured solution was measured relative to the solution of benzidine

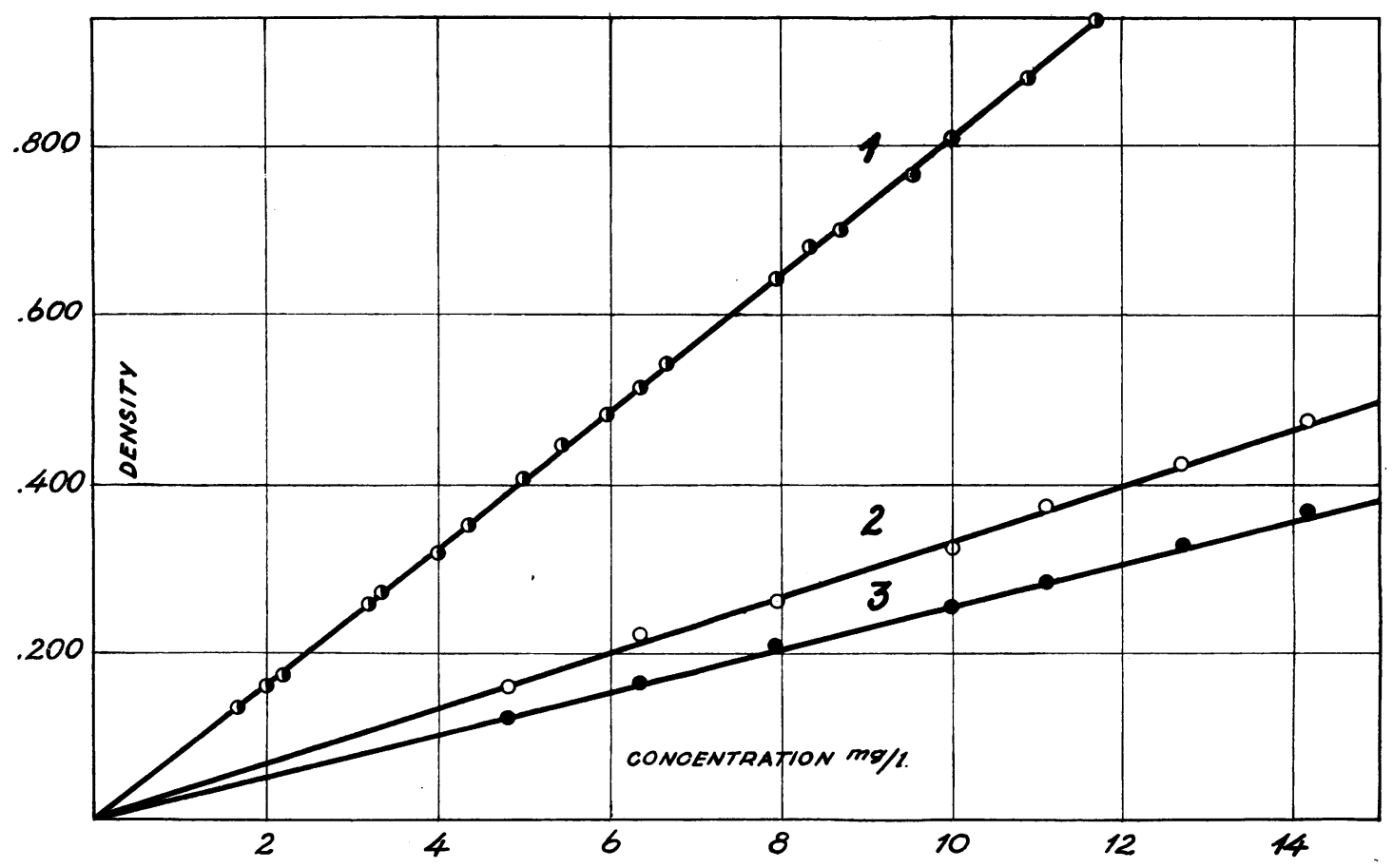

Fig. 3. - Calibrating curves for three different types of photometer. $1=$ Beckman spectrophotometer with $\lambda=400 \mathrm{~m} \mu$, slit $0.06 \mathrm{~mm}$.; $2=$ Fisher electrophotometer, Model A.C. with light filter B $(425 \mathrm{m \mu}) ; 3=$ Pulfrich photometer with filter K-8a-VI (blue). 
$(0.2 \mathrm{~g}$./litre). The constant in the equation was calculated by the least squares method the additional condition being that the straight line should pass through the origin. The probable error of the constant was found to be 0.00027 or $0.34 \%$. The wavelength of light was $400 \mathrm{~m} \mu$, the slit $0.06 \mathrm{~mm}$. This wavelength was chosen because the density of the coloured solution is high enough, while the density of benzidine solution is still negligibly small at this wavelength. For longer wavelengths the intensity of the colour reaction decreases rather rapidly, and hence the sensitivity of the method becomes less. For shorter wavelengths the density of the benzidine solution becomes very high.

Straight line No. 2 on the same figure shows the relation between the concentration and the density for the Fisher electrophotometer. The straight line is not so steep ( $d=0.0332 \mathrm{c})$, and consequently the sensitivity of the method is less. This is probably due to the longer wavelength at which the measurements were performed $(425 \mathrm{~m} \mu)$ and the greater band width transmitted through the filter on the one hand, and to the influence of light on the intensity of the colour reaction on the other. The measurement of the transmission of light takes longer and therefore the reaction mixture is exposed to light for longer periods (see Fig. 1).
The worst results were obtained with the Pulfrich photometer (straight line No. 3). The reasons are the same as for the Fisher instrument. Owing to the design of the apparatus the densities measured are in fact the minimum values on the curve of Fig. 1 corresponding to the colour reaction developed in light. The constant in the equation is 0.0256 .

The ratios of the constants for these three photometers are

$$
0.0808: 0 \cdot 0332: 0.0256=3 \cdot 16: 1 \cdot 3: 1
$$

Thus the method is three times more sensitive if the measurements of density are performed with the Beckman photometer in darkness than if the density is measured with the Pulfrich photometer in light. In other words, with the Beckman spectrophotometer differences in concentration of T.N.M. of $0.1 \mu \mathrm{g} . / \mathrm{ml}$. can be registered with precision, while with the Fisher or Pulfrich instruments differences should be three to five times as large (the error of a single measurement of density being also larger than 0.003 ).

\section{Influence of Ageing of the T.N.M. Solution}

For analytical practice it is important to know whether the analysis of samples should be performed

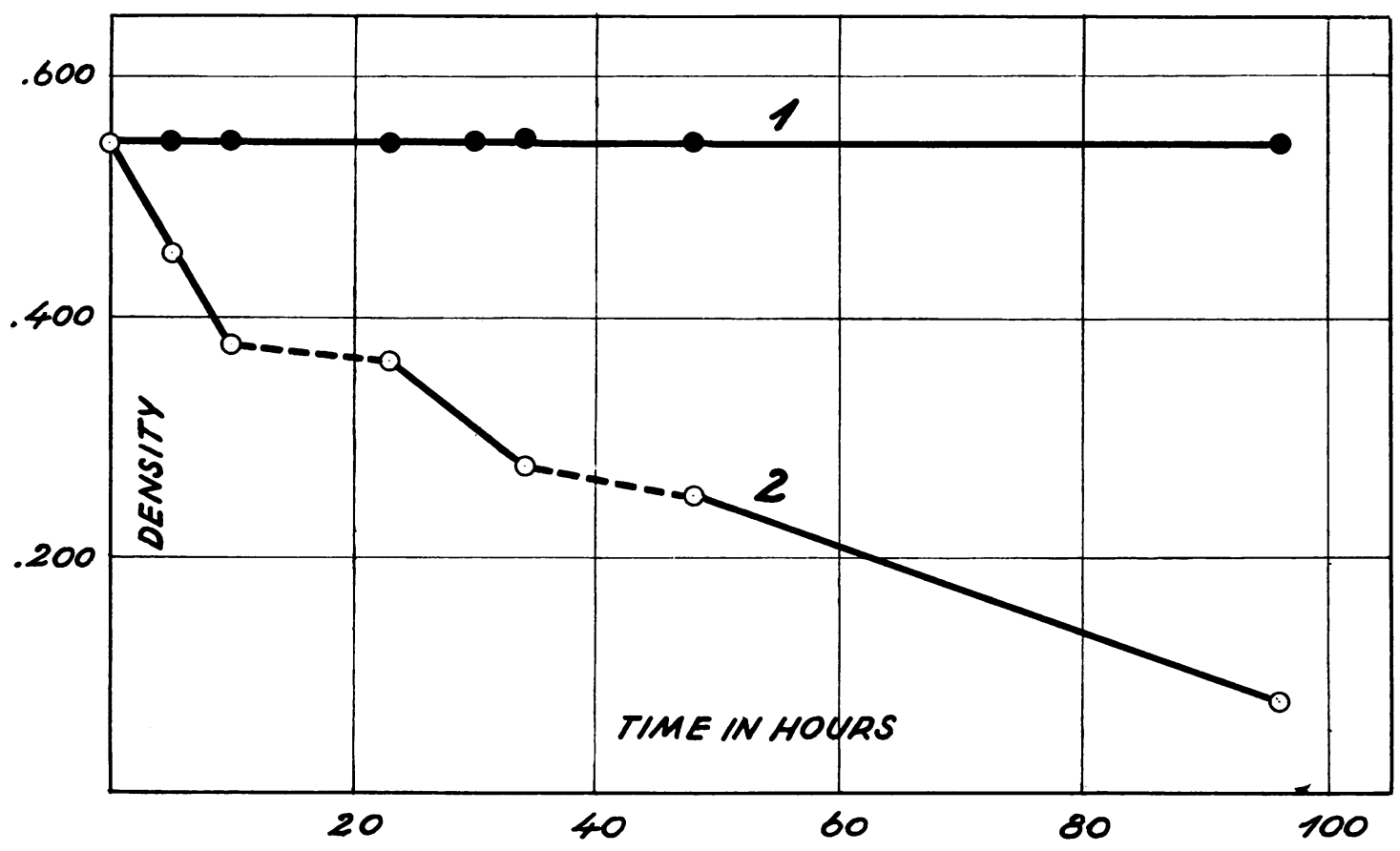

FIG. 4-Graph showing the influence of ageing of T.N.M. solution. Curve 1 denotes density of reaction mixtures prepared with T.N.M. solution kept in darkness; abscissa denotes the age of the T.N.M. solution. Curve 2 denotes density of reaction mixtures prepared with T.N.M. solution exposed to light. 
immediately. The influence of ageing of the T.N.M. solution in ethanol is shown in Fig. 4.

Curve 1 shows the change in the density of the coloured solution with ageing of the T.N.M. solution used for carrying out the reaction if the T.N.M. solution is kept in darkness. The results show that in this case the age of the T.N.M. solution has no influence. However, if the T.N.M. solution is exposed to light the intensity of the colour reaction decreases with the ageing of the T.N.M. solution (Curve 2). These findings differ from Kranz and Stepanek's observations that the T.N.M. solution in ethanol changes when exposed to light only if potassium iodide is present. This curve also shows that the change in the T.N.M. solution is slowed down during the night (dotted parts of the curve).

The benzidine solution also changes when left standing in light. This is a well known fact.

\section{Sampling}

We investigated also the influence of the sampling rate and the concentration of T.N.M. in air on the absorption of T.N.M. in alcohol. The results are given in Table 1. Two or three midget-impingers connected in series and each filled with $10 \mathrm{ml}$. of ethanol served as absorption vessels. The influence of the sampling rate on the absorption capacity of alcohol is marked. The greater the sampling rate, the less T.N.M. is retained in the first impinger. If the concentration of T.N.M. in air does not exceed 25 p.p.m., and the sampling rate is about 0.5 litres/ min., impinger I retains $98.6 \%$ of the total amount of T.N.M. At T.N.M. concentrations of 80 p.p.m. and sampling rates of $1 \cdot 35$, approximately $6 \%$ of T.N.M. goes in the second impinger. For high concentrations and sampling velocities a third impinger should be included in the sampling set.

However, such extreme concentrations never occur in practice. Therefore, it is certainly true that for all practical purposes two impingers filled with $10 \mathrm{ml}$. ethanol each represent a good trap for T.N.M. vapours.

During sampling the room temperature was $25^{\circ} \mathrm{C}$.

TABLE 1

DISTRIBUTION OF TETRANITROMETHANE (T.N.M.) IN A SERIES OF THREE IMPINGERS FILLED WITH ETHANOL

\begin{tabular}{|c|c|c|c|c|c|c|c|}
\hline \multirow{2}{*}{$\begin{array}{c}\text { Sample } \\
\text { No. }\end{array}$} & \multicolumn{2}{|c|}{$\begin{array}{c}\text { Tetranitromethane } \\
\text { Concentration in Air* }\end{array}$} & \multicolumn{2}{|c|}{ Sampling } & \multicolumn{3}{|c|}{ Amount in Impinger (\%) } \\
\hline & (mg./l.) & (p.p.m.) & Rate (1./min.) & Volume (1.) & I & II & III \\
\hline \multirow[t]{2}{*}{$\begin{array}{l}1 \\
2 \\
3 \\
4\end{array}$} & \multirow[t]{2}{*}{$\begin{array}{l}0 \cdot 18 \\
0.18 \\
0 \cdot 17 \\
0.17\end{array}$} & \multirow[t]{2}{*}{$\begin{array}{l}22 \cdot 3 \\
22 \cdot 3 \\
21 \cdot 5 \\
21 \cdot 0\end{array}$} & \multirow[t]{2}{*}{$\begin{array}{l}0.428 \\
0.428 \\
0.428 \\
0.428\end{array}$} & $\begin{array}{l}1.0 \\
1.0 \\
1.0 \\
1.0\end{array}$ & $\begin{array}{l}98 \cdot 4 \\
98.4 \\
98 \cdot 8 \\
99.0\end{array}$ & $\begin{array}{l}1.6 \\
1.6 \\
1.2 \\
1.0\end{array}$ & - \\
\hline & & & & Average & $98 \cdot 6$ & $1 \cdot 4$ & \\
\hline \multirow[t]{2}{*}{$\begin{array}{r}5 \\
6 \\
7 \\
8 \\
9 \\
10 \\
11\end{array}$} & \multirow[t]{2}{*}{$\begin{array}{l}0.56 \\
0.66 \\
0.65 \\
0.34 \\
0.32 \\
0.34 \\
0.33\end{array}$} & \multirow[t]{2}{*}{$\begin{array}{l}70 \cdot 5 \\
82 \cdot 4 \\
81 \cdot 0 \\
43 \cdot 0 \\
39 \cdot 8 \\
42 \cdot 4 \\
41 \cdot 7\end{array}$} & \multirow[t]{2}{*}{$\begin{array}{l}1.0 \\
1.0 \\
1.0 \\
1.0 \\
1.0 \\
1.0 \\
1.0\end{array}$} & $\begin{array}{l}1.0 \\
1.0 \\
1.0 \\
1.0 \\
2.0 \\
2.0 \\
2.0\end{array}$ & $\begin{array}{l}96.0 \\
93.4 \\
95.0 \\
93.2 \\
94.1 \\
93.0 \\
94.6\end{array}$ & $\begin{array}{l}4 \cdot 0 \\
6 \cdot 6 \\
5 \cdot 0 \\
7 \cdot 8 \\
5 \cdot 9 \\
7 \cdot 0 \\
5 \cdot 4\end{array}$ & $\begin{array}{l}0.0 \\
- \\
- \\
- \\
-\end{array}$ \\
\hline & & & & Average & $94 \cdot 2$ & $5 \cdot 8$ & \\
\hline \multirow[t]{2}{*}{$\begin{array}{l}12 \\
13 \\
14 \\
15 \\
16\end{array}$} & \multirow[t]{2}{*}{$\begin{array}{l}0.73 \\
0.68 \\
0.65 \\
0.63 \\
0.61\end{array}$} & \multirow[t]{2}{*}{$\begin{array}{l}90 \cdot 7 \\
86 \cdot 0 \\
80 \cdot 2 \\
78 \cdot 6 \\
78 \cdot 2\end{array}$} & \multirow[t]{2}{*}{$\begin{array}{l}1 \cdot 35 \\
1 \cdot 35 \\
1 \cdot 35 \\
1 \cdot 35 \\
1 \cdot 35\end{array}$} & $\begin{array}{l}1.35 \\
1.35 \\
1.35 \\
1.35 \\
1.35\end{array}$ & $\begin{array}{l}94 \cdot 7 \\
93 \cdot 5 \\
94 \cdot 5 \\
94 \cdot 8 \\
93 \cdot 5\end{array}$ & $\begin{array}{l}5 \cdot 3 \\
6 \cdot 5 \\
5 \cdot 5 \\
5 \cdot 2 \\
6 \cdot 5\end{array}$ & $\begin{array}{l}- \\
- \\
-\end{array}$ \\
\hline & & & & Average & $94 \cdot 4$ & $5 \cdot 6$ & \\
\hline $\begin{array}{l}17 \\
18 \\
19 \\
20 \\
21 \\
22 \\
23\end{array}$ & $\begin{array}{l}0.67 \\
0.43 \\
0.63 \\
0.32 \\
0.39 \\
0.41 \\
0.49\end{array}$ & $\begin{array}{l}84 \cdot 3 \\
53 \cdot 5 \\
78 \cdot 4 \\
40 \cdot 3 \\
48 \cdot 4 \\
51 \cdot 5 \\
61 \cdot 6\end{array}$ & $\begin{array}{l}2 \cdot 1 \\
2 \cdot 2 \\
3 \cdot 25 \\
3 \cdot 75 \\
4 \cdot 1 \\
4 \cdot 1 \\
4 \cdot 85\end{array}$ & $\begin{array}{l}2 \cdot 1 \\
4 \cdot 4 \\
3 \cdot 25 \\
3 \cdot 75 \\
8 \cdot 2 \\
4 \cdot 1 \\
4 \cdot 85\end{array}$ & $\begin{array}{l}92.2 \\
91.5 \\
91.9 \\
91.4 \\
92.8 \\
89.7 \\
90.1\end{array}$ & $\begin{array}{l}7 \cdot 8 \\
8 \cdot 5 \\
8 \cdot 1 \\
7 \cdot 0 \\
6 \cdot 5 \\
9 \cdot 2 \\
9 \cdot 9\end{array}$ & $\begin{array}{l}- \\
- \\
1.6 \\
0.6 \\
1.1 \\
-\end{array}$ \\
\hline
\end{tabular}

* As calculated from the total amount of T.N.M. found in the impingers. 
The Influence of Other Contaminants

With regard to the influence of other contaminants, our results tally well with the results obtained by Sievers and others (1947). Nitrobenzene, p-nitrotoluene, toluene, xylene, benzene, $\mathrm{NaNO}_{2}$ and $\mathrm{HNO}_{3}$ in molar concentration 50 times larger than the molar concentration of T.N.M. have no appreciable influence on the intensity of colour reaction (Table 2). The only exception is p-nitrophenol which exerts a greater influence. However, such an excess of this contaminant is not likely to be encountered in field measurements.
Analysis.-An aliquot volume (1 to $9 \mathrm{ml}$.) of T.N.M. solution depending upon the concentration of T.N.M. vapours in air is pipetted in a measuring flask of $25 \mathrm{ml}$. and the $p \mathrm{H}$ of the solution brought to 6 by adding the necessary amount of purest pyridine. ( $p \mathrm{H}$ may be estimated by nitrazine paper manufactured by E. R. Squibb and Sons, New York.) Benzidine solution, $5 \mathrm{ml}$., $(1 \mathrm{~g}$. purest benzidine dissolved in 1 litre of redistilled alcohol freshly prepared or kept in a dark place) is then added and the mixture made up to $25 \mathrm{ml}$. with ethanol. All these operations should be performed in

TABLE 2

INFLUENCE OF CONTAMINANTS ON INTENSITY OF COLOUR REACTION : TETRANITROMETHANE-BENZIDINE

\begin{tabular}{|c|c|c|c|c|c|c|}
\hline \multirow{2}{*}{\multicolumn{3}{|c|}{$\begin{array}{l}\text { Concentration of } \\
\text { Contaminants } \\
\text { (mg. } / 25 \mathrm{ml} \text {.) }\end{array}$}} & \multicolumn{4}{|c|}{ Density (Extinction) of the Reaction Mixture + Contaminant } \\
\hline & & & \multirow{2}{*}{$\begin{array}{r}\text { Ethanol } \\
0.000\end{array}$} & \multirow{2}{*}{$\begin{array}{c}0.2 \mathrm{ml} . \text { Pyridine } \\
5.0 \mathrm{ml} . \text { Benzidine } \\
\text { Ethanol ad } 25 \mathrm{ml} . \\
0.011\end{array}$} & \multirow{2}{*}{\begin{tabular}{|c|}
$\begin{array}{c}0.2 \mathrm{ml} \text {. Pyridine } \\
7 \times 10^{-7} \text { gmoles T.N.M. } \\
\text { Ethanol ad } 25 \mathrm{ml} .\end{array}$ \\
0.002
\end{tabular}} & \multirow{2}{*}{$\begin{array}{c}0.2 \text { ml. Pyridine } \\
7 \times 10^{-7} \text { gmoles T.N.M. } \\
5.0 \mathrm{ml} \text {. Benzidine } \\
\text { Ethanol ad } 25 \mathrm{ml} . \\
0.518\end{array}$} \\
\hline- & & - & & & & \\
\hline Nitrobenzene & $\cdots$ & 0.43 & 0.012 & 0.026 & 0.018 & 0.548 \\
\hline p-Nitrophenol & . & 0.49 & $0 \cdot 151$ & $0 \cdot 278$ & 0.454 & 0.640 \\
\hline p-Nitrotoluene & $\cdots$ & $0 \cdot 48$ & 0.020 & $0 \cdot 041$ & $0 \cdot 026$ & $0 \cdot 544$ \\
\hline Toluene & . & $0 \cdot 32$ & 0.000 & 0.014 & 0.004 & 0.522 \\
\hline Xylene & . & 0.37 & 0.003 & 0.028 & 0.008 & 0.538 \\
\hline Benzene & . & $0 \cdot 27$ & 0.010 & 0.022 & 0.006 & 0.533 \\
\hline $\mathrm{NaNO}_{2}$ & $\cdots$ & $0 \cdot 24$ & 0.007 & 0.027 & 0.017 & $0 \cdot 507$ \\
\hline $\mathrm{HNO}_{3}^{*}$ & $\cdots$ & $0 \cdot 22$ & 0.010 & 0.039 & 0.007 & $0 \cdot 517$ \\
\hline
\end{tabular}

* The concentration of pyridine in the reaction mixture $+\mathrm{HNO}_{3}$ was $3 \cdot 2$ vol.\%.

\section{Conclusion}

In view of all these results we may state that the Sievers reaction with some modifications may serve as an excellent method for determining small amounts of T.N.M. in air. We propose the following modified procedure.

\section{Modified Procedure}

Sampling.-The air is aspirated through a set of two midget impingers each filled with $10 \mathrm{ml}$. of redistilled commercial ethanol connected in series. On the available data, it is suggested that the sampling rate should not exceed 1.0 litre per minute. As soon as the sampling is completed, the impingers with T.N.M. solution should be put in a dark place. darkness. The reaction mixture prepared in this way should be left to stand in a dark place for at least 15 to 20 minutes. The density of the mixture is then measured with a Beckman spectrophotometer at $\lambda=400 \mathrm{~m} \mu$, slit $0.06 \mathrm{~mm}$.; the standard for comparison is a solution containing $0.2 \mathrm{mg}$. of benzidine in $1 \mathrm{ml}$. of ethanol.

The concentration of tetranitromethane in the solution is read from the diagram (Fig. 3) or calculated from the equation $\mathrm{c}=12 \cdot 4 \mathrm{~d}$.

If this procedure is followed closely, T.N.M. in amounts of $2 \mu \mathrm{g}$. per millilitre can be determined with a probable error of not more than $1.3 \%$. Hence the maximum air sample necessary for precisely determining T.N.M. in industrial air (maximum allowable concentrations $\sim 0.5$ p.p.m.) is 5 litres, when the volume of the absorption liquid is not more than $10 \mathrm{ml}$. 
REFERENCES Baillie, A., Macbeth, A. K., and Maxwell, N. J. (1920). J. Chem.
Soc., 117, 880.

Cruse, K., and Haul, R. (1949). Z. Elektrochem., 53, 115

Ehrenberg, L., Fisher, I., and Löfgren, N. (1945). Svensk. Kem. Tid., 57, 303.

Elkins, H. P. (1950). " The Chemistry of Industrial Toxicology." New York.
Gibson, K. S., and Balcom, M. M. (1947). U.S. Department of Commerce National Bureau of Standards Research Paper, 38, 1798.

Kranz, C. K. and Štepanek, J. M. (1937). Chem. Obzor., 12, 85

Poe Liang (1941). Org. Syntheses, 21, 105-7.

Reid, E. W., and Hoffmann, H. E. (1929). Ind. Eng. Chem., 21, 695.

Scott, E. W. (1943). J. ind. Hyg. Toxicol., 25, 20.

Sievers, R. F., Rushing, E., Gay, H., and Monaco, A. R. (1947). U.S. Public Health Reports, 62 , 1048. 